\title{
Heredity and Alcoholism in the Medical Sphere: The Netherlands, 1850-1900
}

\author{
STEPHEN SNELDERS, FRANS J MEIJMAN and TOINE PIETERS*
}

Father smiled pleasantly and said ... Heinrich cannot disown the hour through which he came into the world. In his speech boils the fiery wine that I had then brought from Rome and that glorified our wedding night. ${ }^{1}$

The effective and real medicinal method to prevent alcohol abuse is to cure its predisposition and for me the only way to do this appears to be to prevent the reproduction of these individuals. ${ }^{2}$

The diversity of opinions around alcohol use and its connections to heredity in the nineteenth century are well illustrated by the two quotations above. By 1900 it was generally accepted that chronic alcoholism could be inherited or transmitted to descendants as morbid nervous predisposition. Together with tuberculosis and syphilis, alcoholism was regarded as a major cause of degeneration and as such defined as a public threat that should be curbed by public health measures. In a number of countries support was mounting for "hard-line" policies of eugenics, such as marriage restrictions and involuntary sterilizations. But other scenarios of fighting the "alcoholism peril" were also enacted. To understand how these scenarios took shape in medicine in the second half of the nineteenth century, we need to take into account the diversity and fluidity of medical and public debates around degeneration and heredity. We also have to pay attention to the continuously changing information regarding heredity emanating from German, French, and British centres of medical research. From this perspective we will raise the question: what were the connections between various concepts of heredity and the medical and social problem of alcoholism?

It is commonplace in the historical literature to relate medical positions on alcoholism in the nineteenth century to evolving concepts of degeneration and heredity. ${ }^{3}$ Two recent

(C) Stephen Snelders, Frans J Meijman and Toine Pieters 2007

* Dr Stephen Snelders, Professor Frans J Meijman, Professor Toine Pieters are all members of the Department of Metamedica, VU University Medical Centre, Postbus 7057, 1007 MB Amsterdam, The Netherlands.

This article is a revised version of a paper given by the first author at the workshop 'A Cultural History of Heredity III: Nineteenth to Early Twentieth Century', Max-Planck-Institute for the History of Science, Berlin 13-16 Jan. 2005.

Abbreviations: GB: Geneeskundige Bladen uit Kliniek en Laboratorium voor de praktijk (Papers from the Clinic and Laboratory for Medical practice); $G C$ : Geneeskundige Courant voor het Koninkrijk der
Nederlanden (Medical Journal for the Kingdom of the Netherlands); $M W$ : Medisch Weekblad voor Noord-en Zuid-Nederland (Medical Weekly for the Northern and Southern Netherlands); NTvG: Nederlandsch Tijdschrift voor Geneeskunde (Dutch Journal for Medicine); $P B$ : Psychiatrische Bladen (Psychiatric Papers); PNB: Psychiatrische en Neurologische Bladen (Psychiatric and Neurological Papers).

\footnotetext{
${ }^{1}$ Novalis, Heinrich von Ofterdingen: ein Roman, Stuttgart, Philipp Reclam jun., 2004, p. 14.

${ }^{2} \mathrm{G}$ Jelgersma, review of De Wegwijzer, PNB, 1897 , 1: $287-94$, on p. 291.

${ }^{3}$ For an overview of the rise of this relationship between alcoholism and degeneration, see W F Bynum, 'Alcoholism and degeneration in 19th century European medicine and psychiatry', Br. J. Addiction, 1984, 79: 59-70; Jean-Charles Sournia, A history of alcoholism, Oxford, Basil Blackwell, 1990, pp. 98-114.
} 


\section{Stephen Snelders, Frans J Meijman and Toine Pieters}

volumes illustrate these accounts of nineteenth-century approaches to degeneration and hereditary diseases such as alcoholism. Craig Heron, in his history of alcoholism in Canada, writes about the last decades of the century:

The growing numbers of physicians who believed inebriates had inherited their "craving" for alcohol shared the environmentalist concern that these degenerates be confined under medical care at an early stage, in the hope of weaning them from their destructive habit. Yet most of those in the medical profession who believed in the crucial importance of heredity saw little hope for drunkards in the end and took limited interest in them. Doctors' optimism about institutional treatment for any kind of mental-health problem was waning by the end of the nineteenth century. Prevention became more important than cure. ${ }^{4}$

The same position is held by John W Crowley and William L White in their history of the first US asylum for alcoholics, the New York State Inebriate Asylum in Binghamton, which opened in 1864. They write:

Whereas "made" drunkards were capable of responding to the care of moralists and reformers, "born" drunkards should be placed in the hands of professional authorities, who would control them by legal or medical means. The appropriate object of such control was the congenital dipsomaniac, whose chances of full recovery were deemed to be small but whose threat to society was deemed to be large. ${ }^{5}$

In both studies alcoholism shows a Janus face: it is a cause as well as a product of degeneration, a vice as well as a malady. Such readings are in line with the idea put forward by some historians that medical hereditarianism in the nineteenth century became increasingly deterministic and fatalistic with concomitant implications in medical and public domains. This is supposed to have happened because a "hardening" of hereditarianism explained the failure of medicine to find cures for alcoholism and other diseases. ${ }^{6}$ But the thesis of a "hardening" hereditarianism has also been combined with a thesis of a "hardening face of nature" in scientific and cultural understandings, where nature was transformed from the benevolent entity of the Enlightenment to the locus of a harsh struggle for survival. ${ }^{7}$

Alcoholism provides an exemplary case study of the dynamics of medical hereditarianism, since it was considered to be an important cause and consequence of degeneration, resulting in mental disease. As Gianna Pomata has written, "It is significant that most of

\footnotetext{
${ }^{4}$ Craig Heron, Booze: a distilled history, Toronto, Between the Lines, 2003, p. 143.

${ }^{5}$ John W Crowley and William L White, Drunkard's refuge: the lessons of the New York State Inebriate Asylum, Amherst, University of Massachusetts Press, 2004, p. 77. See also William L White, Slaying the dragon: the history of addiction treatment and recovery in America, Bloomington, Chestnut Health Systems, 1998; Sarah W Tracy and Caroline Jean Acker (eds), Altering American consciousness: the history of alcohol and drug use in the United States, 1800-1920, Amherst, University of Massachusetts Press, 2004; Howard I Kushner, 'Taking biology seriously: the next task for historians of addiction?', Bull. Hist. Med., 2006, 80: 115-43.

${ }^{6}$ Sheila Faith Weiss, Race hygiene and national efficiency: the eugenics of Wilhelm Schallmayer,
}

Berkeley, University of California Press, 1987, p. 19; Ian Robert Dowbiggin, Keeping America sane: psychiatry and eugenics in the United States and Canada, 1880-1940, Ithaca, Cornell University Press, 1997, pp. ix-x; John C Waller, "“The illusion of an explanation": the concept of hereditary disease, 1770-1870', J. Hist. Med. Allied Sci., 2002, 57: 410-48; idem, 'Poor old ancestors: the popularity of medical hereditarianism, 1770-1870', in 'A cultural history of heredity', Berlin,

Max-Planck Institut für Wissenschaftsgeschichte, Preprint 247, 2003, vol. 2, pp. 131-44, website: $<$ http://www.mpiwg-berlin.mpg.de/Preprints/P247. pdf $>$

${ }^{7}$ Gianna Pomata, 'Comments', in 'A cultural history of heredity', op. cit., note 6 above, pp. 146-51, on p. 151. 


\section{Heredity and Alcoholism in the Medical Sphere}

the 19th century doctors' interest in hereditary diseases shifted from gout, the patrician malady, to insanity - a disease considered to be endemic at the other end of the social ladder." 8 We therefore wish to focus on the questions of how, to what extent, and why knowledge of inheritance was anchored in medical concepts and practices around alcoholism.

The case study centres on the roles played by notions of heredity in Dutch medicine, by analysing discourses on prevention and treatment of alcoholism and alcohol abuse in the Dutch medical literature. The Dutch are not regarded as pioneers of medical and political activities in this field. It might therefore be that a focus on the Netherlands shows developments representative of mainstream developments in western medicine that are not allowed for in the works cited above. Furthermore, since the organized eugenic movement was only of limited significance in the Netherlands even in the twentieth century, the Netherlands appear an exemplary case for investigating influences and implications of differentiated concepts of heredity outside the eugenic problem field. ${ }^{9}$

The study operates on two analytical levels. First, there is the level of theory and conceptualization within medicine; second, we distinguish the level of application and practical approaches. Medicine is a field in which a logical coherence between these two levels often seems to be lacking: it is a science as well as an art. ${ }^{10}$ In medical practice "elastic" approaches dominate, given the unruly nature of medicine. Connecting concepts of hereditary disease to those of individual constitutions did not necessarily entail a desire on the part of physicians to rationalize and to excuse their inability to treat a range of persistent chronic maladies, including alcoholism. It could also justify an elastic approach in treatment, undisturbed by hereditary determinism. Discourses of conceptualization as well as practices of treatment and prevention have both to be put into context. On each of these levels more, broader cultural themes and social beliefs, in this case especially that of degeneration, become apparent.

\section{Concepts: The Hereditary Influence of Alcoholism}

At the start of the twentieth century Dutch doctors took the concept of hereditary predisposition to alcoholism for granted. In this, they followed mainstream international developments. Dutch academics and doctors in general knew their languages. Dutch medical journals were very aware of and followed the developments in Germany, France, and Britain. Research reports translated from the German, French, and British literature, which appeared in Dutch medical journals over the course of the 1890s, and were based on pedigree research and statistical studies of the inmates of asylums, seemed to establish beyond doubt certain facts. Alcoholism (or dipsomania as it was alternatively called) had a strong tendency to be hereditary. However, in most cases it changed its form and manifested itself in other mental diseases. Inmates of asylums were to a large but disputed degree hereditary insane due to the influence of alcoholism; as we will see below, estimates

\footnotetext{
${ }^{8}$ Ibid., p. 150 .

${ }^{9}$ The standard history of eugenics in the Netherlands is Jan Noordman,

Om de kwaliteit van het nageslacht.
}

Eugenetica in Nederland 1900-1950, Nijmegen,
SUN, 1989.
${ }^{10}$ D J Weatherall, Science and the quiet art: medical
research and patientcare, Oxford University Press, 1995. 


\section{Stephen Snelders, Frans J Meijman and Toine Pieters}

went as high as over 40 per cent. The hereditary influence of alcoholism expressed itself in different forms: directly as delirium tremens and periodic bouts of alcohol abuse; indirectly in psychoses; and biologically in "deprivation of the progeny" and extinction in the third and fourth generation. This pathological form of heredity could be transmitted by inheritance due to chronic alcohol abuse by one or both of the parents, or through alcohol poisoning of the germ plasma during sexual intercourse, or because of what we would call foetal conditioning because of an alcoholic mother. ${ }^{11}$ Fairly indicative of medical opinion around 1900 was that of the physician J Kat, an active member of the temperance movement, on the influence of alcohol on posterity. He claimed that "Das grauige Kapital" ("the drab capital", i.e. the influence of alcohol abuse by parents before and during conception) was the cause of the greatest part of retardation, imbecility, idiocy, epilepsy, neurasthenia, and criminality, as was proved by health statistics produced by researchers all over the world. ${ }^{12} \mathrm{~A}$ similar but in terms of degenerative heredity more articulate view can be found in the New Year speech to Amsterdam doctors given by the gynaecologist Hector Treub in 1900. According to Treub, there existed five "laws of heredity": (1) direct inheritance from the parents; (2) inheritance of traits from an earlier generation, i.e. atavism; (3) indirect or collateral inheritance from a collateral family line; (4) "initial inheritance" from the condition of the parents during cohabitation: for example, a drunk parent increased the chance for idiocy in the child; (5) inheritance of influence, or telegony: for instance, a white woman cohabitating with a negro would give birth to a mulatto. If she later cohabitated with a white man, the child would again be a mulatto.

Treub was rather sceptical about the fifth law. He mainly engaged with the first three laws, and he came to some far-reaching conclusions. His exposition was in fact meant to stress the necessity of medical investigation and advice on heredity before marriage. This might seem to point to a "hard" form of hereditarianism, emphasizing genetic determinism and fatalism. ${ }^{13}$ This opens up questions about the transformations of medical thought concerning hereditary transmission.

It is of importance to note that neither Treub's laws nor his methodology were anything new. The original formulation of his laws seems not to have originated in the domain of scientific biology, but could already be found in the ideas and practices of animal breeders. ${ }^{14}$ Treub's laws of inheritance were based on the results of a research method that had long been popular: pedigree research. For instance, Treub used a pedigree taken from

\footnotetext{
${ }^{11}$ For example: S K Hulshoff, review of R Demme, Ueber den Einfluss des Alkohols auf den Organismus des Kindes (Stuttgart, Ferdinand Euke, 1891), NTvG, 1891, 27 (2): 328-30; W Ruysch, report on the Fifth International Congress against Alcohol Abuse in Basel, $N T v G, 1895,31$ (2): 551-5, on p. 554; anonymous editorial report, $N T v G, 1898,34$ (2): 495-7, on p. 496; Hector Treub, 'Huwelijk en ziekte', GB, 1900, 7: 29-48.

${ }^{12} \mathrm{~J}$ Kat, literature review in Centralblatt für Nervenkrankheiten und Psychiatrie, 1902-1903, $N T v G, 1904,40$ (2): 107-8, on p. 108. J Kat, medical superintendent of the State lunatic asylum at Medemblik, was one of the founders of the medical doctors' temperance association in 1898 .
}

\footnotetext{
${ }^{13}$ Treub, op. cit., note 11 above. Hector Treub (1856-1920), from 1886 professor of obstetrics and gynaecology at the University of Leyden, in 1896 moved to the University of Amsterdam. He was a prolific writer of national and international publications. His brother Willem was a member of the liberal government during the First World War.

${ }^{14}$ See Roger J Wood and Vítêzslav Orel, Genetic prehistory in selective breeding, Oxford University Press, 2001; Carlos López-Beltrán, 'In the cradle of heredity: French physicians and L'Héréditénaturelle in the early 19th century', J. Hist. Biol., 2004, 37: $39-72$.
} 


\section{Heredity and Alcoholism in the Medical Sphere}

the most influential medical authority on heredity of the second half of the nineteenth century, the French psychiatrist Bénédict-Augustin Morel. ${ }^{15}$ Treub used this pedigree to demonstrate how chronic alcoholism could lead to idiocy and madness in subsequent generations. ${ }^{16}$ Pedigree study had been pioneered in the 1830 s by Franz Wilhelm Lippich in Laibach. ${ }^{17}$ By the start of the twentieth century this methodology had become the methodology of human genetics. As Pauline Mazumdar has written, pedigrees "made the visible fact of heredity easy and convincing to demonstrate", without necessarily presupposing any particular theory of transmission. ${ }^{18}$ By the 1900 s, the pedigree method "was the eugenist's most typical and effective instrument". 19 This process had started much earlier. In his study, published in 1834, Lippich had given a statistical analysis of 200 alcoholic patients, and found their offspring to be generally more unhealthy than the general population of Laibach. ${ }^{20}$ Morel's treatises on degeneration (1857) and mental illness (1860) stimulated similar studies. His own pedigree research famously demonstrated the hereditary degeneration caused by alcoholism: in the first generation moral stupefaction, brutalization, and weakening of the body; in the second, hereditary drunkenness, mania and palsy; in the third, hypochondria and suicidal tendencies; and finally in the fourth generation, mental defects, idiocy, and premature death, ultimately leading to extinction of the family. In Morel's analysis, alcoholism showed its Janus face as vice and malady, as cause and consequence of hereditary predispositions and vicious environments. ${ }^{21}$

But did Morel offer anything sensationally new in the conceptualization of alcoholism? The impact of his work may have been due more to the elaboration of existing notions than to a revolutionary new approach. Even before Morel published his volumes, in 1852 the leading Dutch psychiatrist Johan N Ramaer had emphasized that inebriety was the cause of hereditary mental diseases, primarily idiocy. Ramaer referred to Lippich's evidence, but also to the knowledge of this hereditary degeneration among the ancient Greeks. ${ }^{22}$

Over the course of the next half a century this theory of degeneration was repeated again and again, occasionally confirmed by new family studies. We did not find any divergent

\footnotetext{
${ }^{15}$ Bénédict-Augustin Morel (1809-1873), director of the lunatic asylum of Maréville (Meurthe) 18481856, from 1856 director of the asylum of Saint-Yon (Seine-Inférieure).

${ }^{16}$ Treub, op. cit., note 11 above, p. 34.

${ }^{17}$ Franz Wilhelm Lippich (or Lippic) (1799-1845), in 1832 he became district physician in Laibach in the Austrian Empire, in 1834 he was made professor of medicine at the University of Padua, and in 1841 was given the same position at the University of Vienna.

${ }^{18}$ Pauline M H Mazumdar, Eugenics, human genetics, and human failings: the Eugenics Society, its sources and its critics in Britain, London, Routledge, 1992 , p. 71.

${ }^{19}$ Ibid., p. 80.

${ }^{20}$ W F Bynum, 'Chronic alcoholism in the first half of the 19th century', Bull. Hist.Med., 1968, 57: 160-85, on pp. 175-6.

${ }^{21}$ Bénédict-Augustin Morel, Traité des dégénérescences physiques, intellectuelles et morales
}

de l'espèce humaine, Paris, Baillière, 1857; idem, Traité des maladies mentales, Paris, Masson, 1860. On Morel, see Jean-Christophe Coffin, 'Heredity, milieu and sin: the works of Bénédict Augustin Morel (1809$1873)$ ', in 'Cultural History of Heredity', op. cit., note 6 above, pp. 153-64.

${ }^{22}$ J N Ramaer, Dronkenschap en krankzinnigheid. Eene voorlezing, Tiel, Gebr Campagne, 1852, pp. 97-100. Johan Nicolaas Ramaer (1817-1887), from 1841 until 1863 he was physician at the lunatic asylum of Zutphen. In 1863 he moved to the lunatic asylum of Delft where he remained until 1869. In 1872 he became an inspector of mental hospitals, and in 1884 Inspector of the State Superintendence of Lunatics. One of the founders of both the Dutch Society for Medicine in 1849 and the Dutch Association for Psychiatry in 1871, Ramaer had the reputation of being an excellent psychiatrist and was one of the most influential doctors in the profession. 


\section{Stephen Snelders, Frans J Meijman and Toine Pieters}

opinions; in the Dutch medical literature from the 1850s until Treub's lecture in 1900, Morel was again and again cited as the authority and evidence for the Janus face of alcoholism. Medical journals never doubted the scientific truth of Morelian degeneration. ${ }^{23}$ The leading hygienist Levi Ali Cohen incorporated the views of Morel in his public health manual of $1872 .{ }^{24}$ So, twenty years later, did the psychiatrist Pierre F Spaink in his 1892 monograph on alcoholism. ${ }^{25}$ Jan Broers in his 1886 doctoral thesis on alcoholism, morphinism and chloralism, the first Dutch medical treatise on the general subject of addiction, lamented that chronic alcoholism especially had the "important disadvantage" that posterity had to suffer for the sins of its ancestors. ${ }^{26}$ In Morelian degeneration vice becomes the disease of the descendants, and disease becomes the vice of the descendants.

Leading articles in medical journals routinely explained the degenerative effects of alcoholism on succeeding generations. ${ }^{27}$ In 1884 the psychiatrist Antonius Tellegen did not doubt the hereditary consequences of alcoholism, but recognized that statistics on the hereditary aetiology of madness differed widely, from 4 per cent to 90 per cent. But this was explainable because persons could have the predisposition to madness, but die before this predisposition was expressed. ${ }^{28}$ After Morel, the relationship between hereditary degeneration and alcoholism was endorsed by family studies; only the exact percentage of the predisposed varied. The Dutch medical press reported that Rudolf Demme from the University of Bern had confirmed Morel's conclusions in 1890 in his study of twenty families, in which one or both of the parents were alcoholics, over a period of twelve years. Of 57 children, only 10 (17.5 per cent) developed normally; 25 had died in the first weeks after birth, and 22 showed congenital defects-defective physical development, chorea, epilepsy, idiocy. In a group of ten families with moderate drinkers as parents, 50 of the 61 children had grown up healthy (81.9 per cent). ${ }^{29}$ In 1895 it was reported that in the asylum of the French psychiatrist Maurice Legrain 42.6 per cent of the inmates were hereditary insane due to the influence of alcoholism. ${ }^{30}$ Similar conclusions had been reached in 1898

\footnotetext{
${ }^{23}$ Anon., 'Erfelijke krankzinningheid', GC, 1870, 24, no. 10 (6 March); anon., 'Erfelijke dronkenschap', 1877, 31, nos 49 (9 Dec.), 50 (16 Dec.), 51 (23 Dec.).

${ }^{24} \mathrm{~L}$ Ali Cohen, Handboek der openbare gezondheidsregeling en der geneeskundige politie, met het oog op de behoeften en de wetgeving van Nederland, Groningen, J B Wolters, 1872, p. 156. This textbook was one of the most important manuals of the hygienist movement in the Netherlands. Levi Ali Cohen (18171889) was a general practitioner in Groningen from 1840 until 1865, when he became Medical Inspector for the provinces of Overijssel and Drenthe, and from 1868 also of Friesland and Groningen (i.e., the northern provinces of the Netherlands).

${ }^{25}$ Pierre F Spaink, Over alcoholismus, Amsterdam, J H \& G van Heteren, 1892, pp. 19-20. Spaink was director of a private mental asylum in Apeldoorn.

${ }^{26}$ Jan Broers, Alcoholisme, morphinisme, chloralisme, op zich zelf en in verband met elkaar beschouwd, Beverwijk, D S Slotboom, 1886, p. 125. Broers (1860-1940) specialized in dermatology and started practice in The Hague in 1900.
}

\footnotetext{
${ }^{27} \mathrm{M}$ Niermeijer, 'Alcohol en alcoholisme', $G C$, 1895, 49, no. 31 (4 Aug.); A N J Hanedoes van Almkerk, 'Alcoholisme en de houding van medici te dien opzichte', $G C, 1900, \mathbf{5 4}$, no. 10 (11 March).

${ }^{28}$ A O H Tellegen, 'Eenige beschouwingen over krankzinnigheid, hare oorzaken en hare behandeling', $P B, 1884,11: 5-46$. Antonius Otto Hermannus Tellegen (1848-1904) became second physician at the Coudewater lunatic asylum at Plasmolen in 1878; from 1885 until 1888 he was first physician at the Voorburg mental hospital at Vught, and from 1892 until 1898 managing director of the lunatic asylum at The Hague. From 1888 he practised as a psychiatrist in The Hague. He was editor of $P B$.

${ }^{29} \mathrm{~S}$ K Hulshoff, review of R Demme, Ueber den Einfluss des Alkohols auf den Organismus des Kindes (Stuttgart, Ferdinand Euke, 1891), NTvG, 1891, 27 (2): 328-30.

${ }^{30} \mathrm{~W}$ Ruysch, report on the Fifth International Congress against Alcohol Abuse in Basel, $N T v G, 1895$, 31 (2): 554. Maurice Paul Legrain (1860-1939) was co-author, with Valentin Magnan, of the influential
} 


\section{Heredity and Alcoholism in the Medical Sphere}

in a study of 1200 cases of hereditary insanity by Robert Farquharson in Britain. ${ }^{31}$ And in 1899 the news was that research in Bonn had uncovered 709 descendants of a "well-known" alcoholic woman who had died in 1800. Of these descendants 462 had become murderers, criminals, beggars, or prostitutes, and had cost the German government six million francs. ${ }^{32}$ A further important argument for medical and public health measures against alcohol abuse and alcoholism was therefore situated in an economic case for efficiency: in modern terminology, measures against alcoholism would prove "cost-effective".

\section{Concepts: Hereditary Transmission and Evolution}

How did all this relate to the dynamic and controversial discussions about biological evolution in this period? The connecting of degeneration theory and evolutionism started in the Dutch medical literature in the early 1880s. This suggests that the impact of Darwin on the medical framing of alcoholism and degeneration was almost non-existent in the 1860s and 1870s. Darwin's work was not relevant in any way to this framing, for which Morel was a sufficient authority. The theory of degeneration was as acceptable to those physicians who supported the new evolution theories, as to their more traditional and religious minded colleagues. Morel himself was not, of course, a Darwinist in any sense. He was a Catholic who framed degeneration in terms of the Fall of Man. ${ }^{33}$

The great challenge to conceptions of alcoholism and heredity in the medical domain was provided by August Weismann's (1834-1914) new notion of the "germinative plasma". Weissman's theory had a major impact on the redefinition of the concepts of heredity at the end of the nineteenth century. Starting from the question of how the germ plasma carrying inherited characteristics could reproduce itself, Weissman conceptualized the soma, the body, as a mere transport vehicle for the germ plasma. In doing so he separated the problem of heredity from that of growth and differentiation. Changes in the soma were not transmittable to the germ plasma. Weismann "proved" in 1883 that traits acquired during a lifetime could not be inherited by descendants. However, this proof did not have the impact in the medical domain that historians of biology have often accorded to it. ${ }^{34}$

The Dutch anatomist Willem Koster discussed the matter in 1886. He called Weismann's Bedeutung der sexuellen Fortpflanzung für die Selektions-Theorie a "phantastic-speculative evolution theory", that seemed to contradict established pathological and clinical knowledge. The leading German pathologist Rudolf Virchow gave acclimatization as an example of the inheritance of acquired characteristics, while

treatise on degeneration: Les dégénérés (état mental et syndromes épisodiques), Paris, Rueff, 1895.

${ }^{31}$ Editorial report, $N T v G, 1898,34$ (2): 495-7, on p. 496. The Scottish physician Robert Farquharson (1836-1918) practised at St Mary's Hospital in London and was a member of the House of Commons.

${ }^{32} \mathrm{Z}$ (probably B G van der Hegge Zijnen), 'De afstammelingen van een alcoholist', $G C, 1899,49$ : no. 40 (1 Oct.).

\footnotetext{
${ }^{33}$ Rafael Huertas, 'Madness and degeneration, I. From "fallen angel" to mentally ill', Hist. Psychiatry, 1992, 3: 391-411, on pp. 394-5.

${ }^{34}$ On the debatable idea that Weismann disproved the inheritance of acquired characteristics, see Peter J Bowler, The non-Darwinian revolution: reinterpretating a historical myth, Baltimore, Johns Hopkins University Press, 1988, pp. $115-18$.
} 


\section{Stephen Snelders, Frans J Meijman and Toine Pieters}

Weismann was of the opinion that the acclimatized individual was already, by chance, adapted to his new environment. Koster thought that Weismann's idea of the continuity of the germ plasma explained much, for example, the inheritance of the "Jewish type". But, if Weismann was right, hereditary infectious diseases could not exist. However, syphilis and tuberculosis were regarded as ample proof for the claim of the hereditability of these common diseases. ${ }^{35}$

A year later, a leading article in the Geneeskundige Courant (Medical Journal) clearly stated that, under specific conditions, acquired characteristics could be inherited. Why this happened was still a mystery; that it did happen was beyond doubt. Weismann notwithstanding, the article informed its readers that the acquired character, developed by education, environment, etc., the "envelope" of the true, inherited character, later changed again into the inherited character, because it was inherited by the descendants. Not the characteristics themselves, but the predisposition to develop them was inherited. Expression depended on circumstances. The more often characteristics occurred in pedigrees, the greater the chance that they would return in later generations. A person with a powerful imagination could transfer his acquired characteristics more easily to his descendants: the example given was that of an alcoholic father. Inheritance of equal characteristics occurred in pedigrees, but more often polymorphism, the unequal distribution of dispositions. Expression of these predispositions was dependant on circumstances: for example, shock, misery, strain. Under the right circumstances, the predisposition could even express itself as genius, as in the case of Schopenhauer. Morel's pedigrees once again figured prominently to demonstrate the mechanisms and patterns of hereditary transmission. ${ }^{36}$

This perspective of a plasticity of expression was compatible with existing medical traditions. It did not conflict either with the new theory of evolution as expressed by Darwin. It was recognized that Darwin himself believed in the inheritance of acquired characteristics. ${ }^{37}$ But the medical community could also incorporate Weismann's ideas. In 1891 Hendrik Zwaardemaker, one of the editors of the most important medical journal Nederlandsch Tijdschrift voor Geneeskunde (Dutch Journal for Medicine), called Weismann's theory a hypothesis of great value, an advance in the direction of a mechanical explanation of nature. There was much that seemed to support Weismann, such as the occurrence of atavisms and of morphological characteristics that were insurmountable for the individual, but not for the species as a whole. Still, the theory was far from proven. ${ }^{38}$ Koster in turn undertook another review of Weismann in 1893. There was no evidence for the inheritance of acquired characteristics in a positive sense, he wrote, but Weismann did not deny "inheritance in a negative sense": agents such as alcohol or virus syphiliticum

\footnotetext{
${ }^{35} \mathrm{~W}$ Koster, 'Ontwikkelingsleer en ziektekunde', $N T v G, 1886,22$ (1): 341-9. Willem Koster (18341907) became professor of anatomy at the University of Utrecht in 1862 but had to retire for health reasons in 1888. After that he devoted himself to medico-social studies, for instance a study on the laws of heredity and the increase in mental deficiency published in 1900 .

36 'De overerving van zenuw- en zielsziekten', $G C$, 1887, 41: nos. 22 (29 May), 23 (5 June), 24 (12 June).
}

\footnotetext{
37 'De overerving van verworven eigenschappen', $G C, 1889,43$ : no. 43 (27 Oct.).

${ }^{38} \mathrm{H}$ Zwaardemaker, review of J F van Bemmelen, De erfelijkheid van verworven eigenschappen ('s-Gravenhage, n.p., 1890), $N T v G, 1891,27$ (1): 418-20. Hendrik Zwaardemaker (1857-1930) was an army medical doctor from 1882 until 1897, then became professor of physiology at the University of Utrecht 1897-1927. He was internationally wellknown for his experimental physiological research.
} 


\section{Heredity and Alcoholism in the Medical Sphere}

could damage sperm cells and lead, when sperm and egg mingled, to a spontaneous poisoning of the germ plasma. ${ }^{39}$

This "inheritance in a negative sense" became in the course of the 1890s as satisfactory and convenient an explanation for the hereditary degeneration caused by alcoholism as the inheritance of acquired characteristics had been. What we have here is a typical form of medical eclecticism, producing a workable explanatory tool that met a need, based on doctors' experiences and seemingly proven by empirical pedigree studies. Possible inconsistencies between the above mentioned biological concepts were noted but amended and adjusted to produce a medical argument consistent with a perspective of plastic expression of hereditary predisposition. ${ }^{40}$ It is important to look at the adjustment and amendments in the knowledge of heredity expressed by doctors from a functionalist perspective, and not from the perspective of consistency with developments in the scientific sphere.

At the end of the century there was consensus about the three possible mechanisms by which alcoholism could be inherited and which explained both Treub's "laws of inheritance" and the onset of the degeneration process, i.e. the transformation of a somatic disorder into morbid nervous dispositions. As the authoritative Swiss researcher and temperance activist Auguste Forel explained at the Fourth International Congress against Alcohol Abuse in The Hague in 1892, alcohol itself was a toxic agent that led to degeneration of progeny. ${ }^{41}$ Alcohol abuse by the mother could lead to poisoning of the foetus in utero. Blastotoxie occurred when a child was conceived while one or both of the partners in the sexual act were drunk. A third mechanism, Blastophtorie, functioned when one of the parents was a chronic alcoholic whose germ plasma was seriously poisoned by the alcohol. ${ }^{42}$

While in accordance with neo-Darwinism, this plastic perspective on hereditary transmission also fitted into Morelian degeneration schemes. Even the possible positive implications of the inheritance of acquired characteristics were saved: over several generations, healthy living could restore the vitality of the germ plasma. ${ }^{43}$ Jacobus van Rees, a physician and leading prohibitionist in the Netherlands, explained in a 1902 propaganda brochure against alcohol use that the germ plasma could regenerate in the third or fourth generation, providing that it was mixed with undamaged plasma. ${ }^{44}$ Forel furthermore

\footnotetext{
${ }^{39}$ W Koster, 'De toeneming der krankzinnigheid', $N T v G, 1893,29$ (2): 293-311, on pp. 306-7.

${ }^{40}$ For similar developments in France, see Patrice Pinell, 'Degeneration theory and heredity patterns between 1850 and 1900,' in Jean-Paul Gaudillère and Ilana Löwy (eds), Heredity and infection: the history of disease transmission, Routledge, London, 2001, pp. 245-59.

${ }^{41}$ J L C G A Le Rütte Jr, 'Het vierde internationale congres tot wering van het misbruik van sterken drank', $P B, 1892,11: 220-1$. Auguste Forel (1848-1931), Swiss psychiatrist, was professor of psychiatry and director of the lunatic asylum at Burghölzi 1877-1898. After 1898 he devoted himself to private research and became an authority on wide ranging subjects such as hypnotism, ants, and alcoholism. Forel was one of the most important spokesmen of the European temperance movement.
}

\footnotetext{
${ }^{42}$ On these views, see Claus Finzen, 'Der Alkoholismus als Problem der Degeneration um die Jahrhundertwende', MD thesis, University of Kiel, 1977, p. 31.

${ }^{43}$ Ibid., p. 33

${ }^{44} \mathrm{~J}$ van Rees, 'De invloed van de alkohol op het kind vóór de geboorte (erfelijkheid)', in J van Rees, Theodor Ziehen, A Don, Het kind en de alcohol, Amsterdam, Hoofdbestuur der Ned. Onderw. Propaganda-Club voor drankbestrijding, 1902, pp. 1-8. Jacobus van Rees (1854-1928) was a histologist and worked with Weismann in Freiburg from 1883 until 1885. In 1886 he became lector of physiology at the University of Amsterdam, in 1889 extraordinary professor, and retired in 1924. A disciple of Tolstoy, he participated in the founding of a Tolstoyan community in Blaricum in 1899 that broke up after a few years. He was a prominent member of the temperance movement.
} 


\section{Stephen Snelders, Frans J Meijman and Toine Pieters}

maintained that man had a "plastic" disposition: the expression of hereditary disposition could take different forms, depending on opportunity and exercise; it did not have to take a pathological form per se. ${ }^{45}$ The elastic nature of attempts by Dutch doctors at adjusting theories on heredity to medical problems raises the question of their conclusions regarding alcoholism treatment and prevention policies.

\section{Approaches: Public Health}

Dutch doctors regarded alcohol abuse and alcoholism as both an individual and a public health problem. The problem of the consumption of strong liquor, especially the Dutch jenever (geneva), was particularly high on their agenda. Quite a number of physicians, however, considered fermented drinks such as beer and wine as nutritious and stimulating to health. Concerns about the consumption of jenever were not a new feature of the $1850 \mathrm{~s}$, but had existed since at least the eighteenth century. ${ }^{46}$ In 1854 Nicolaas B Donkersloot, the Dutch psychiatrist and editor of the Geneeskundige Courant, put the abuse of strong liquor on a par with the state lottery as one of the two great disasters that had overtaken the Netherlands. ${ }^{47}$ Not only was the use of strong liquor an individual health problem, since it badly affected physical health and was the cause of mental and moral aberrations, it was also a public problem, since it meant economic misfortune for consumers (who spent their money on drink) and destroyed religion and higher morality. Donkersloot pleaded for the prohibition of jenever, a policy he would continue to advocate until his death in $1890 .^{48}$

It is easy to see that the Morelian twist to the degeneration story fitted the politically conservative Donkersloot like a glove. Furthermore, it is remarkable that Donkersloot's views on jenever were exactly the same as those of one of the leading Dutch liberal hygienists, Levi Ali Cohen, almost two decades later. In his public health manual of 1872, Ali Cohen named the use of jenever as the chief source of the misery of the Dutch people. He expanded the usual description of jenever's health hazards with the consequences for posterity as described by Morel. ${ }^{49}$ Like Donkersloot, but unlike most of their colleagues, Ali Cohen was also concerned about the physiological effects of fermented alcohol. In 1863 he had already referred to French research that had shown that beer and wine were "false" nutrients, since they diminished the effectiveness of real nutrition. Their only value lay in their therapeutic use in medicine, as stimulants. ${ }^{50}$

\footnotetext{
${ }^{45} \mathrm{P}$ F Spaink, review of Deutsche Wochenschrift, 1894 , no. $52, N T v G, 1895,31$ (1): 324-7, on p. 324.

${ }^{46}$ For analyses of the British "gin craze", one of the first modern drug scares, see Jessica Warner, Craze: gin and debauchery in an age of reason, New York, Random House, 2002; Patrick Dillon, The muchlamented death of Madam Geneva: the eighteenthcentury gin craze, Boston, Justin, Charles, 2003.

${ }^{47}$ Nicolaas Bernard Donkersloot (1813-1890) participated in 1831 as military medical officer in the campaign against the Belgian insurgents. In 1835 he became a surgeon and obstetrician in Amerongen, and took his MD degree in 1843 in Utrecht. In 1847 he was the founder and, until his death, editor of $G C$. Between
}

1859 and 1880 he was medical superintendent of the lunatic asylum at Dordrecht, and from 1880 had a psychiatric practice in The Hague. With Ramaer, he was one of the founders of the Dutch Association for Psychiatry and editor of $P B$ 1883-1885.

${ }^{48} \mathrm{~N}$ B Donkersloot, Loterij en jenever. Twee rampen over Nederland, Tiel, H C A Campagne, 1854.

${ }^{49}$ Ali Cohen, op. cit., note 24 above, pp. 155-60.

${ }^{50} \mathrm{~L}$ Ali Cohen, report on research, NTvG, 1863, first series, 7: 664-5; second series 1865, 1 (1): 523-33. On nineteenth-century therapeutic use of alcohol, see Harry W Paul, Bacchic medicine: wine and alcohol therapies from Napoleon to the French paradox, Amsterdam, Rodopi, 2001. 


\section{Heredity and Alcoholism in the Medical Sphere}

The question of the nutritious and therapeutic value of alcohol was one of the few questions regarding the effects of the drug that physicians continued to discuss in the medical press.

By the 1890s these discussions had internationally become associated with those over whether physicians should advocate moderation, as the majority obviously did, or whether they should preach abstinence. These debates could be fierce as they were at the Fourth International Congress against Alcohol Abuse in The Hague in 1892, with Forel as foremost spokesman for the extremists. ${ }^{51}$ Three years later, at the next international congress, the issue was even more hotly argued. The Dutch Inspector of the State Superintendence of the Insane,Wilhelm P Ruijsch, reported that the moderates (such as himself) were treated as traitors by their opponents. ${ }^{52}$ The psychiatrist Pierre F Spaink was saddened by the exaggerations of the advocates of prohibition. Alcohol had its use as medication, he thought, although he prohibited such use in his own asylum in Apeldoorn. ${ }^{53}$

Hardly any commentators questioned the public health hazards of chronic alcohol abuse. Ali Cohen and other hygienists allied themselves politically to the liberals, while Donkersloot was politically conservative. But their position on the alcohol problem was the same, and Ali Cohen too advocated preventive and repressive measures in this "war on alcohol". These strong opinions of prominent members of the medical profession contributed to the enactment of the first Dutch law on alcohol use (Drankwet) of 1881. This law to some extent regulated the trade in distilled liquor by preventive and repressive measures (such as limitation of the number of pubs and the prohibition of liquor sales to children younger than sixteen), and made public inebriety an offence. Before the First World War more than 4000 men and women would end up doing forced labour in state prisons for this offence. ${ }^{54}$

The temperance movement regarded this law as totally inadequate, but the whole spectrum of opinion within the medical profession (that is the opinions expressed in the medical press), was convinced of the need for state regulation in the fight against alcohol abuse. However this did not extend to legal prohibition, partly because Dutch physicians were clearly too fond of their own alcohol intake. The 1900 diatribe of A N J Hanedoes van Almkerk, medical superintendent of the first Dutch asylum for alcoholics, in the Geneeskundige Courant against any use of alcohol was coincidentally accompanied by an advertisement for a wine seller. ${ }^{55}$ At the general meeting of the Dutch Society for the

\footnotetext{
${ }^{51}$ Anon., report on Fourth International Congress against Alcohol Abuse in The Hague, $N T v G, 1893,29$ (2): $321-3$.

${ }^{52} \mathrm{~W}$ Ruysch, report on the Fifth International Congress against Alchohol Abuse in Basel, $N T v G$, 1895, 31 (2): 551-2. Wilhelm Pieter Ruysch (18471920) worked at the Ministry of the Interior from 1884. He succeeded Ramaer in 1887 as Inspector of the State Superintendence of the Insane. In 1902 he became Chief Inspector of Public Health, and in 1912 President of the Health Council, the most important medical advisory committee of the government. From 1897 until 1904 he was president of the social-democratic temperance league de Volksbond tegen drankmisbruik (People's League against Alcohol Abuse).
}

\footnotetext{
${ }^{53} \mathrm{P}$ F Spaink, review of report on the influence of alcohol on children by the Department of Amsterdam of the Nederlandsche Onderwijzers-Propaganda-Club, $N T v G, 1895,31$ (1): 92-3; idem, review of Deutsche Wochenschrift, 1894, no. 52, NTvG, 1895, 31 (1); 324-7, on p. 326.

${ }^{54}$ Jacob Carel van der Stel, Drinken, drank en dronkenschap. Vijf eeuwen drankbestrijding en alcoholhulpverlening in Nederland, Hilversum, Verloren, 1995, p. 156.

${ }^{55}$ Hanedoes van Almkerk, op. cit., note 27 above. Hanedoes van Almkerk was medical superintendent of the first asylum for alcoholics in the Netherlands, HoogHullen, founded in 1891, and one of the co-founders of the medical doctors' temperance association in 1898.
} 


\section{Stephen Snelders, Frans J Meijman and Toine Pieters}

Advancement of Medicine in 1901 the representative of the city of Dordrecht argued that it was not the task of the Society to prohibit alcohol use. He provoked laughter when he added: "This representative has at least not noticed anything of this these days [at the social gatherings between the meetings]." Donkersloot did not regard legal measures against public inebriety as adequate, although Donkersloot did advocate fines and, for a second offence, loss of citizen's rights. ${ }^{57} \mathrm{He}$ consistently argued that the only sufficient measure was to make alcohol a prescription drug. Other, less satisfactory, measures could be a state monopoly on the sale of alcohol and the closure of the jenever pubs on Sunday and on Monday morning. ${ }^{58}$ Donkersloot and his collaborators also advocated occasional forced abstinence for alcoholics. ${ }^{59}$ After his death in 1890, Donkersloot's successors at the Geneeskundige Courant continued to warn against the dangers of alcohol and alcoholism. They advised physicians to set a good example and to proselytize against alcohol abuse. They advocated making alcohol a prescription drug, and warned against the degeneration of progeny, and against the introduction of absinthe. ${ }^{60}$

The historical paradox in all this is that the per capita consumption of alcohol in the Netherlands, distilled liquor as well as alcohol, had already started to fall from around 1880 (after a sharp rise in the 1860s and 1870s), a fall that cannot be attributed to any public health measure. Only after 1960 did alcohol consumption increase again. ${ }^{61}$

\section{Approaches: Eugenic Policies?}

In the 1880 s and 1890 s some voices were heard in the Dutch medical literature that seemed to point to greater support for eugenic policies based on genetic determinism and fatalism. These voices run parallel to the "hardening" of hereditarianism in the biological sciences. This parallel development should not, however, seduce us into making any causal connections. Possible policy implications of the various biological theories are seldom discussed; an exception to this was Koster in 1886. According to Koster, the inheritance of acquired characteristics provided some hope that a policy of (social) hygiene could create a better species, whereas Weismann's theories led only to the prospect of a Spartan state, in which the inferior had to be eliminated. Koster's line of argument here shows rather close similarities with a neo-Lamarckian perspective on positive eugenics. ${ }^{62}$ But on the whole it was not hereditarianism that hardened, but rather the conclusions of some doctors concerning public health and prophylaxis. However, these voices remained a minority with no political impact.

\footnotetext{
${ }^{56}$ Anon., report of the general meeting of the Nederlandsche Maatschappij tot Bevordering der Geneeskunde, $N T v G, 1901,37$ (2): 152-4, on p. 153.

${ }^{57}$ Editorial, GC, 1870, 24: no. 23 (5 June); anon., 'Beteugeling der dronkenschap', ibid., 1880, 34: nos. 40 (3 Oct.), 41 (10 Oct.), 42 (17 Oct.), 43 (24 Oct.), 44 (31 Oct.).

${ }^{58}$ [N B Donkersloot], 'Het alkoholisme, zijn verspreiding, werking op het persoonlijk en maatschappelijk organisme, en de middelen om het te bestrijden', $G C$, 1879, 33: nos. 5 (2 Feb.), 6 (9 Feb.), 7 (16 Feb.).
}

${ }^{59} \mathrm{D}$ [N B Donkersloot], review of C S Adama van Scheltema, Volksonderwijs over alcohol, n.p., n.d., GC, 1879, 33: no. 26 (29 June); editorials, $G C, 1888,42$ : nos. 5 (29 Jan.), 49 (2 Dec.).

${ }^{60} \mathrm{C}$ W Bollaan, review of P F Spaink, Over alcoholismus (Amsterdam, van Heteren, 1892), GC, 1892, 46: no. 38 (18 Sept.); Niermeijer, op. cit., note 27 above; editorial on absinthe, $C G, 1894,48$ : no. 12 (25 March).

${ }^{61}$ Van der Stel, op. cit., note 54 above, pp. 68-9.

${ }^{62}$ Koster, op. cit., note 35 above. 


\section{Heredity and Alcoholism in the Medical Sphere}

A first eugenic voice (although in no way connected to a "eugenic movement") could be heard in 1884. It was based, not on hard hereditarianism, but on the "proven" inheritance of acquired characteristics. The psychiatrist Tellegen drew a provisional conclusion from this theory: physicians should advise couples before marriage about the heritability of certain diseases present in their pedigrees. In fact he was simply advocating a practice that was current among at least a minority of physicians. ${ }^{63}$ His public mention of it was novel, but far from new in medical practice. Treub took in 1900 basically the same position as Tellegen, since he asked for medical advice before marriage that was not legally binding. ${ }^{64}$

A language which we might associate with "modern eugenics" seems to be slowly emerging here. The psychiatrist Gerbrandus Jelgersma ${ }^{65}$ expressed his doubts in 1897 about the goals of the temperance movement: was prohibition of strong liquor indeed the effective method to reduce significantly the number of the mentally insane (by as much as one-third, as the temperance activists claimed), and of criminals and beggars (the greater part, they claimed)? The figures from those "dry" American states where prohibition ruled suggested otherwise to Jelgersma. He found the American experience unsurprising, since alcohol abuse from a scientific point of view was as much a consequence as a cause of insanity. Where the "weak" were not able to get alcohol, they ruined themselves by other means: in "dry" Iowa the use of opium had increased. Jelgersma's is the first voice in the Dutch medical press before 1900 that sounds distinctly "social-Darwinist" in the modern popular sense. Prohibition would be counterproductive, since it would only keep the weak alive and allow them to reproduce themselves. It would interfere with natural selection. Jelgersma therefore considered the état maladif, the pathogenic predisposition, to be the cause of alcohol abuse and insanity, that should be controlled-by legal regulation of reproduction. Jelgersma did not deny the efficacy of anti-alcohol propaganda in cases of alcohol abuse with a non-hereditary aetiology: the great number of people who suffered from the increased demands and stress of modern society, and who sought escape and relaxation in drink. For these the activities of the temperance movement were very well suited. But the hereditarily predisposed should not be allowed to reproduce. ${ }^{66}$

Jelgersma's plea for legislation was a very solitary one before 1900_even Treub did not want to go that far. Another "new" method that combined with the ancient fears of degeneration was Neo-Malthusianism, with its advocacy of anticonception. At the end of our period, in 1899, the Rotterdam practitioner J Elias combined the old theories of degeneration with theories about abnormal embryogenesis resulting from influences of an hereditary (for example, Blastotoxie during conception) or environmental (for example, detrimental diet) character, to advocate that physicians should assist nature by "Neo-Malthusian" methods. ${ }^{67}$

\footnotetext{
${ }^{63}$ Tellegen, op. cit., note 28 above, pp. 18-25. On the survival of this practice in the United States, see Martin S Pernick, The black stork: eugenics and the death of "defective" babies in American medicine and motion pictures since 1915, New York, Oxford University Press, 1996.

${ }^{64}$ Treub, op. cit., note 11 above, pp. 44-5.

${ }^{65}$ Gerbrandus Jelgersma (1859-1942) worked as a prosector at the Meerenberg psychiatric asylum and as a private lecturer in criminal anthropology at the
}

University of Amsterdam. In 1894 he became medical superintendent of the sanatorium for nervous diseases at Arnhem, and in 1899 professor in psychiatry and neurology at the University of Leiden. He wrote a threevolume textbook of psychiatry (1911-12) and was the first to introduce Freud's theories to Dutch academic debate.

${ }^{66} \mathrm{G}$ Jelgersma, review of De Wegwijzer, $P N B$, 1897, 1: 287-94.

${ }^{67} \mathrm{~J}$ Ph Elias, 'Degeneratie', $M W, 1899,6$ : 137-40, 149-51, 249-50, 267-9, 278-86. 


\section{Stephen Snelders, Frans J Meijman and Toine Pieters}

The primary interest here lies in the evidence that "eugenic" ideas of regulation of reproduction by regulation of marriage were actually already present and even accepted by physicians in the second half of the nineteenth century. The concept kept a low profile, however, because it did not extend, or only occasionally, to demands for public legislation or anticonception. We must remember here that eugenic thought in various countries (but not in the Netherlands) primarily made its essential impact on state legislation in the political, social and economic crises of the interwar period. ${ }^{68}$

\section{Approaches: Individual Health}

In practice, doctors had to deal more with individual patients and their treatment options than with public health strategies. What can we say about the dynamics of concepts regarding heredity and alcoholism and individual health approaches?

First of all, we must discount one important historiographical notion about the treatment of alcoholism in the nineteenth century: the myth of therapeutic pessimism. If anything, the case of alcoholism and heredity shows that the idea of a "hardening" hereditarianism as an explanation of therapeutic failure can not be generalized. Estimates of recovery percentages under an adequate therapeutic regime ran as high as 40 per cent (and as low as 25 or 30 per cent) at the end of the century, a figure given by cautious rather than optimistic authors, and which in 2007 was not surpassed by modern addiction treatment methods. ${ }^{69}$ Of course we should not take these figures at face value, but they clearly indicate something other than therapeutic pessimism. This does not mean that such pessimism cannot be found in the Dutch medical press. In 1888 the psychiatrist Pieter Wellenbergh reported on his visit to the psychiatric hospital in Graz, Austria, run by the eminent degeneration specialist Richard von Krafft-Ebing. According to the latter, psychiatrists should make a distinction between non-hereditary madness, which could be cured in 70 to 80 per cent of the cases, and paranoia, which was the expression of an hereditary predisposition and could only rarely be cured. The implications for the alcoholic seemed evident. ${ }^{70}$

Krafft-Ebing's Dutch colleague Spaink was of the opinion that the symptoms of alcoholism were more severe in hereditary alcoholics. This seemed logical to him, because they were already insane or alcoholic before they had their first drink; after their first drink, their predisposition had to manifest itself. ${ }^{71}$ However this did not lead Spaink to therapeutic pessimism concerning patients with a hereditary predisposition. Hanedoes van Almkerk, medical supervisor of the asylum for inebriates in Hoog-Hullen, described his patients in the most pessimistic and abhorrent terms: "inferior", "incongruency of the brain parts", "Aztec skulls" in a denigratory sense, "predisposed children with the attitude of wild

\footnotetext{
${ }^{68}$ On the relationship between eugenic policies and the state, see the comparative literature review on Britain, the United States, Germany, Sweden, Russia, and the Netherlands in Stephen Snelders and Toine Pieters, "Van degeneratie tot individuele gezondheidsopties. Het maatschappelijk gebruik van erfelijkheidsconcepten in de twintigste eeuw', Gewina, 2003, 26: 203-15.

${ }^{69}$ Anon., $N T v G, 1889,25$ (1): 563; anon., ibid., p. 636; Spaink, op. cit., note 25 above, p. 72.
}

\footnotetext{
${ }^{70} \mathrm{P}$ Wellenbergh, report on visit to German asylums, $P B, 1888$, 6: 96-103. Pieter Wellenbergh (1848-1916) was a psychiatrist at various mental hospitals from 1877 until 1887, after which he started a psychiatric practice in Amsterdam. Richard Freiherr von Krafft-Ebing (1840-1903) was professor of psychiatry and director of the lunatic asylum in Graz 1873-1889. Between 1889 and 1902 he was director of the psychiatric hospital in Vienna.

${ }^{71}$ Spaink, op. cit., note 25 above, pp. 16-17, 26.
} 


\section{Heredity and Alcoholism in the Medical Sphere}

animals". Yet he claimed to cure 75 per cent of patients who stayed for more than one year of treatment, and 25 per cent of those that stayed for a shorter duration. ${ }^{72}$ His abhorrence of degenerates did not lead him to pessimism in his work, although it must be added that of course not all alcoholics in Hoog-Hullen were thought to be hereditarily predisposed to their condition. It was reported that, because 60 per cent of Hoog-Hullen's patients were in their thirties, it was unlikely that hereditary conditions were the main cause of their alcoholism. $^{73}$

Both Spaink and Hanedoes van Almkerk were asylum doctors and had a vested interest in presenting alcoholism as at least partly curable. But other doctors were not wholly pessimistic either with regard to treatment, or with regard to prevention. This fits with the concepts of heredity extensively discussed above. Our thesis is that the discovery of hereditary antecedents in the pedigree of an alcoholic was not necessarily a cause for pessimism because physicians generally thought that the manifestation of the problem was plastic, or fluid, dependent on environment and circumstances. These differences in individual predisposition were associated with the idea that therapy should be "a psychiatric treatment in accordance with the individuality of the patient". ${ }^{74}$ Individual variation also combined with the possibilities of prophylaxis. The physician could, according to Ruijsch, cure where possible, and by his influence with the families of his patients prevent the use of alcohol: by calmly and quietly explaining that it is not necessary for everyone, by banishing it from children's diets, by pointing to alcohol abuse in cases of illness, and to its negative consequences especially for those predisposed to alcoholism. ${ }^{75}$ In general, a hereditary predisposition to insanity in individuals could be countered by the provision of a healthy wet-nurse for young children (in cases of insanity or alcoholism in the mother), caution against the appearance of "brain congestions", and a sensible education. ${ }^{76}$

Plasticity of expression of predisposition and elasticity of treatment theoretically opened the way for, not therapeutic pessimism, but the possibility of the reversal of degeneration. One could read in 1870 in the Geneeskundige Courant about the research results of Morel's French pupil Doutrebente, one of whose conclusions was: "It is beyond doubt that races can regenerate themselves, i.e., that through the influence of a harmless factor at least some of the descendants can climb to a higher position."77 Thirty years later the same position was discussed by van Rees in the terminology of negative inheritance: the damaged germ plasma could regenerate in the third or fourth generation if mixed with new, undamaged plasma. ${ }^{78} \mathrm{We}$ can therefore subscribe to some extent to the conclusion of the study of the German historian Claus Finzen on alcoholism and degeneration in the German-language scientific literature around 1900: many psychiatrists gave their attention to the prophylaxis and treatment of alcoholism precisely because alcoholism was seen as the main cause of mental disease, and work in this field seemed to hold great promise of success. ${ }^{79}$

\footnotetext{
${ }^{72}$ Hanedoes van Almkerk, op. cit., note 27 above.

${ }^{73}$ Anonymous communication regarding a meeting of the Vereeniging ter bevordering van het herstel van drankzuchtigen, $N T v G, 1901,37$ (1): 1333.

${ }^{74}$ Broers, op. cit., note 26 above, p. 30.

${ }^{75} \mathrm{~W}$ Ruijsch, letter to the editors, $N T v G, 1895$, 31 (2): 709-15, on p. 714.
}

\footnotetext{
${ }^{76}$ Van Deventer, 'Eenige opmerkingen over de psychiatrische behandeling van krankzinnigen', $P B$, 1888, 6: $27-8$

77 'Erfelijke krankzinnigheid', $G C, 1870,24$ : no. 10 (6 March).

${ }^{78}$ Van Rees, op. cit., note 44 above.

${ }^{79}$ Finzen, op. cit., note 42 above p. 31.
} 


\section{Stephen Snelders, Frans J Meijman and Toine Pieters}

It seems logical to assume that professional interests played their role in this approach to alcoholism and heredity. As we have seen, in the Netherlands both liberal and conservative doctors, such as Ali Cohen and Donkersloot, were basically in agreement here, which seems to point to other agendas. Alcoholism, precisely because of its dominant role in creating (partly by hereditary transmission) society's mental problems, fulfilled a key function in establishing the claims to importance of fin-de-siècle psychiatry. For Britain, Andrew Scull has concluded that even where madness was resistant to treatment, this did not lead to pessimism or abandonment of intervention, but to a shift in the direction of prevention. ${ }^{80}$ Doctors had a professional interest in not presenting their fight against alcoholism as hopeless, and in proclaiming their unique role in this fight. A role which was increased by the use of psychopharmacological interventions, as we will see now.

Basically, acute and chronic alcoholism were treated similarly, by abstinence, diet, and exercise. ${ }^{81}$ Once again, this was nothing new. Sir Walter Scott described in 1830 the medical treatment of a patient with alcoholism resulting in delirium tremens: "a gentle course of medicine ... retire to [the patient's] own house in the country, observe a temperate diet and early hours, practicing regular exercise . . avoiding fatigue." 82 The historian W F Bynum has concluded on nineteenth-century medical approaches:

Alcoholism and alcohol-related problems could be treated by relatively simple measures like a wholesome diet and complete abstinence from alcoholic beverages. The alcoholic on occasion could be reformed and returned to society; hence the prognosis, even if often perceived to be bleak, was not so grave as that of many [other] asylum patients. ${ }^{83}$

But the second half of the nineteenth century additionally witnessed in the Netherlands and other countries extensive experiments and interventions with psychopharmacological medication. In these fifty years an astounding collection of drugs was tried out, especially to combat the effects of delirium tremens. In the 1850s, opium was still the chief medication in cases of delirium tremens and withdrawal symptoms. The idea was artificially to induce sleep, during which the "anomalies of the brain and nervous system" would automatically disappear. ${ }^{84}$ Opium therefore assisted the body in curing itself. Another drug in use was digitalis. Later in the century, chloral hydrate, morphine, lupuline (in the 1870s), strychnine (in the 1880s), and other medications were used, including purgatives, as well as nausea cures (in which all food and drink was dosed with alcohol). More or less favourable reports on such treatments were regularly published in the medical journals. ${ }^{85}$

The great problem for physicians was not a lack of (more or less) effective treatment methods, but that the generally accepted best treatment method required total abstinence and a retreat from daily life for recovery and cure. However, most actual or potential

\footnotetext{
${ }^{80}$ Andrew Scull, The most solitary of afflictions: madness and society in Britain, 1700-1900, New Haven, Yale University Press, 1993, p. 383.

${ }^{81}$ Broers, op. cit., note 26 above, p. 30; Spaink, op. cit., note 25 above, p. 71.

${ }^{82}$ Walter Scott, Letters on demonology and witchcraft, Ware, Wordsworth Editions, 2001, p. 19. On British medical approaches to alcoholism in the eighteenth and early nineteenth centuries, see Roy Porter, 'The drinking man's disease: the "pre-history"
}

of alcoholism in Georgian Britain', Br. J. Addiction, 1985, 80: 385-96.

${ }^{83}$ Bynum, op. cit., note 3 above, p. 63.

${ }^{84}$ Anonymous communications, $N T v G, 1857$, i: 355,594

${ }^{85}$ For example, editorials, $G C, 1870,24$ : no. 3 (16 Jan.); $G C, 1878,32$ : no. 1 (6 Jan.); $G C, 1880,34$ : no. 25 (27 June); 'Beteugeling der dronkenschap', GC, 1880, 34: no. 41 (10 Oct.); J Hanlo, untitled, NTvG, 1884, 20 (1): 203; anon., $M W, 1895$, i: 646. 


\section{Heredity and Alcoholism in the Medical Sphere}

patients did not have their own country house in which to facilitate their cure. In 1891 a special asylum for inebriates, Hoog-Hullen in Eelde, was opened, directed by a medical supervisor. ${ }^{86}$ But neither this initiative nor changing ideas about heredity led to significant changes in overall medical approaches to alcoholism before 1900. Far from being helpless against alcoholism in its various forms, the physician of the second half of the nineteenth century had an impressive armoury of methods for helping his patients towards cure. Of course there are no reliable figures on the efficacy of these methods, but there was no cause for a priori therapeutic pessimism, nor did concepts regarding heredity lead to such pessimism.

\section{Conclusions}

In the second half of the nineteenth century, doctors in the Netherlands integrated German, French, and British research developments around heredity in a flexible and fluid way in their conceptualizations of and approaches to alcoholism. On a conceptual level, Dutch doctors aimed at the amendment and adjustment of biological theories in the construction of workable explanatory tools. Morelian degeneration, neo-Lamarckian inheritance of acquired characteristics, Darwinian evolution, or Weismannian poisoning of the germ plasma could be and were all used instrumentally to produce these tools. They could be adjusted to explain doctors' experiences of the phenomena of hereditary degeneration, of plastic expression of predispositions, and even of the possibilities for hereditary regeneration. In this regard, it seems highly questionable whether a focus on a "hardening" scientific hereditarianism is particularly relevant for understanding developments in the medical sphere. Here, historical concentration on ideas and concepts appears inadequate.

Public health strategies connected to heredity around 1900 can only tentatively be characterized as primarily concerned with collectives or the "race", and not with individuals. In degeneration theory, vice became the disease of the descendants, and disease became the vice of the descendants. But we have shown that on the level of clinical and practical approaches knowledge of heredity did not necessarily connect to a therapeutic pessimism. The fight against alcoholism, based on flexible concepts of heredity, and incorporating pragmatic and elastic treatment and prevention practices, offered hope for individual cures, as well as being an instrument for the long-term regeneration of the population. It also assisted in establishing the importance of fin-de-siècle psychiatry, precisely because the plasticity of the hereditary predisposition allowed for medical interventions.

Although not static, in the case of alcoholism the medical domain of the Netherlands before 1900 did not experience the grip of a hardening hereditarianism. We might therefore question whether or to what extent this did occur in other countries. The importance and relevance in the past of differentiated and flexible concepts of heredity have often been overlooked by historians. Take, for example, studies of the social hygienic movement in Britain around 1900. This movement has been analysed as essentially a marriage between the late-nineteenth- and early-twentieth-century concepts of heredity and of social hygiene among physicians, politicians, welfare professionals and social reformers, a movement

\footnotetext{
${ }^{86}$ Van der Stel, op. cit., note 54 above, pp. 189-94.
} 
aimed at public health policies and sanitary reforms. In this analysis, eugenic proposals to separate the unproductive unfit, the feebleminded, from the productive fit in the population were part of broader reform programmes aiming at increased national efficiency in the international competition for imperialist supremacy. ${ }^{87}$ Historians critical of this analysis have emphasized environmentalists' distrust of eugenic concepts (for instance, that of the British Medical Officers of Health) ${ }^{88}$ This does not mean however that these officers did not use the knowledge of heredity. The same Medical Health Officers who advocated "environmentalist" reforms appeared influenced by flexible concepts of heredity, in which social reforms were seen as contributing to hereditary regeneration. A relevant exemplary case study has been contributed by Warwick Anderson. Anderson shows that Australian doctors in the nineteenth and early twentieth centuries used various racial and hereditarian concepts in varied and flexible ways. In a perspective that is close to that used in this article, it becomes clear that studying medical practice solely from the perspective of a history of ideas is too blunt a tool. ${ }^{89}$ It remains the challenge for medical historians to discover what actually went on between doctor and patient in the consulting rooms and clinics.

\footnotetext{
${ }^{87}$ Greta Jones, Social hygiene in twentieth century Britain, London, Croom Helm, 1986, pp. 5-10.

${ }^{89}$ Warwick Anderson, The cultivation of whiteness:

${ }^{88}$ Dorothy Porter, " Enemies of the race": science, health, and racial destiny in Australia, New biologism, environmentalism and public health in Edwardian England', Victorian Studies, 1990/91, 34: 159-78, on p. 165.
} 